\title{
PENINGKATAN KEMAMPUAN MENGELOLA KELAS MELALUI TEKNIK PEMODELAN
}

\author{
Siti Muhaiminah \\ SD Muhammadiyah Wonokromo II Pleret, Bantul \\ sitimuhaiminah68@gmail.com
}

\begin{abstract}
Abstrak: Penelitian ini bertujuan untuk mengimplementasikan teknik pemodelan dalam meningkatkan pengelolaan kelas dan meningkatan kemampuan guru dalam mengelola kelas melalui teknik pemodelan di SD Muhammadiyah wonokromo II. Jenis penelitian yang dilakukan yaitu penelitian tindakan sekolah (PTS) dengan menggunakan model dari Elliot. Penelitian diadakan di SD Muhammadiyah Wonokromo II Pleret Bantul pada tahun pelajaran 2017/2018 semester 2. Subjek penelitian adalah guru kelas 1, 2, 3, 4, dan guru Pendidikan Agama Islam. Obyek penelitian adalah kompetensi pengelolaan kelas. Data dikumpulkan melalui observasi dan dokumentasi serta dianalisi secara kualitatif. Hasil penelitian ini menunjukkan bahwa teknik pemodelan dapat meningkatkan kompetensi guru dalam mengelola kelas. Kompetensi guru bidang pengelolaan kelas sebelum ada tindakan sebesar $72 \%$ setelah ada tindakan pada siklus I mencapai $76 \%$ sehingga mengalami peningkatan sebesar $4 \%$. Setelah ada tindakan pada siklus II kompetensi guru bidang pengelolaan kelas mencapai $87 \%$ sehingga mengalami peningkatan $12 \%$.
\end{abstract}

Kata kunci: teknik pemodelan, pengelolaan kelas.

\section{IMPROVING CLASSROOMMANAGEMENT SKILLTHROUGH MODELING TECHNIQUES}

Abstract: This study aims to improve the ability of teachers to manage classes through modeling techniques at SD Muhammadiyah wonokromo II. The type of research conducted is school action research (SAR) using a model from Elliot. The study was held at Muhammadiyah Elementary School Wonokromo II Pleret Bantul in the 2017/2018 academic year 2. The research subjects were teachers of class 1, 2, 3, 4, and Islamic Education teachers. The object of research is class management competence. Data is collected through observation and documentation and analyzed qualitatively. Teacher competency in the field of classroom management before there was an action was $72 \%$ after the action in the first cycle reached $76 \%$ so that it increased by $4 \%$. After there was an action in the second cycle the competence of teachers in the classroom management reached $87 \%$ so that it experienced a $12 \%$ increase.

Keywords: modeling techniques, classroom management.

\section{PENDAHULUAN}

Sekolah merupakan lembaga formal yang bertugas untuk melaksanakan kegiatan belajar mengajar dalam rangka mencapai tujuan pendidikan. Kegiatan belajar mengajar akan berjalan lancar jika komponen-komponen dalam lembaga ini terpenuhi dan berfungsi sebagaimana mestinya. Komponen-komponen tersebut antara lain: sarana dan prasarana yang memadai, terpenuhinya tenaga pendidikan yang qualified, adanya struktur organisasi yang teratur, dan yang tak kalah pentingnya adalah peranan kepala sekolah sebagai supervisor internal dalam mengembangkan komponen-komponen tersebut agar berjalan sesuai dengan tujuan yang diharapkan. Supervisi ini dapat membantu guru dalam melaksanakan pembelajaran termasuk dalam mengelola kelas.
Kemampuan mengelola kelas yang rendah dapat dilihat dari suasana kelas yang kurang kondosif, aktifitas siswa yang kurang terkontrol, minat siswa dalam belajar kurang, siswa tidak semangat dalam melaksanakan kegiatan pembelajaran, kurang motivasi, sehingga berdampak pada rendahnya nilai belajar siswa. Kurangnya kemampuan mengelola kelas adalah sebuah masalah yang harus diatasi.

Ditawarkan solusi untuk mengatasi permasalahan itu dengan menggunakan teknik pemodelan untuk meningkatkan kompetensi pengelolaan kelas. Teknik pelaksanaannya dengan membuat program model mengajar. Kepala sekolah atau guru senior yang dinilai memiliki kemampuan pengelolan kelas yang baik melaksanakan kegiatan belajar mengajar disaksikan oleh subjek penelitian di sekolah tersebut. Guru mengobservasi bagaimana cara 
mengelola kelas yang baik. Beberapa hal yang diobservasi antara lain apersepsi sebelum masuk ke materi yang akan dipelajari (pembentukan dan pengembangan kompetensi), suasana dalam pembelajaran, penggunaan alat atau media, gaya mengajar, pengaturan tempat duduk, dan pola interaksi. Setelah guru selesai menyaksikan pemodelan lalu dilakukan diskusi untuk membahas proses pemodelan. Hal ini diharapkan dapat memberikan salah satu alternative atau referensi guru dalam mengajar. Selanjutnya guru mengajar diobservasi oleh peneliti. Peneliti telah menyiapkan instrumen observasi. Instrumen observasi yang disiapkan adalah RPP guru yang harus disiapkan sebelum mengajar, Pengelolaan kelas saat guru mengajar, keterlibatan siswa saat mengikuti pelajaran, dan hasil evalusi setelah satu tatap muka. Dengan melihat contoh mengajar guru model atau teknik pemodelan ini diharapkan dapat meningkatkan kompetensi guru dalam mengelola kelas.

Pembimbingan dilakukan kepada guru melalui beberapa tahap. Beberapa hal yang ditempuh kepala sekolah yaitu dengan menyelenggarakan workshop cara membuat RPP dan cara mengelola kelas dengan baik. Selanjutnya kepala sekolah memberikan contoh atau model dalam melakukan pembelajaran dengan disaksikan oleh guru. Guru melakukan observasi terhadap model pembelajaran. Guru bisa menyaksikan bagaimana guru model membuka pelajaran, melakukan apersepsi, melakukan kegiatan inti, melakukan interaksi dengan siswa, dan melakukan penilaian.

Keterampilan mengelola kelas
merupakan kemampuan guru dalam mewujudkan dan mempertahankan suasana belajar mengajar yang optimal. Kemampuan ini erat kaitannya dengan kemampuan guru untuk menciptakan kondisi yang menguntungkan, menyenangkan peserta didik dan penciptaan disiplin belajar secara sehat. Mengelola kelas meliputi mengatur tata ruang kelas untuk pembelajaran dan menciptakan iklim pembelajaran yang kondusif. Dalam kaitan dengan pengelolaan kelas ini terdapat beberapa hal yang harus diperhatikan yaitu ruang belajar, pengaturan sarana belajar, susunan tempat duduk, penerangan, suhu, pemanasan sebelum masuk ke materi yang akan dipelajari.
Pengelolaan kelas dapat mempengaruhi tingkat kualitas pembelajaran di kelas karena susasana kelas menjadi baik sehingga siswa menjadi nyaman dan senang selama mengikuti proses belajar mengajar. Oleh karena itu, kualitas belajar siswa seperti pencapaian hasil yang optimal dan kompetensi dasar yang diharapkan dapat tercapai dengan baik dan memuaskan. Pengelolaan kelas juga akan menciptakan dan mempertahankan suasana kelas agar kegiatan mengajar dapat berlangsung secara efektif dan efisien. Pengelolaan kelas yang baik akan meningkatkan daya serap materi yang telah diajarkan guru, dan akan lebih membekas dalam ingatan siswa karena adanya penguatan yang diberikan guru selama proses belajar mengajar berlangsung.

Senduk dan Nurhadi (2003:50) berpendapat bahwa pemodelan atau teknik modeling adalah salah satu dari tujuh komponen pembelajaran kontekstual. Maksudnya, dalam sebuah pembelajaran keterampilan atau pengetahuan tertentu, ada model yang bisa ditiru. Pemodelan pada dasarnya membahasakan gagasan yang dipikirkan, mendemonstrasikan bagaimana guru menginginkan siswanya untuk belajar dan melakukan apa yang guru inginkan agar siswanya melakukan. Pemodelan dapat berbentuk demonstrasi, pemberian contoh tentang konsep atau aktivitas belajar. Dengan kata lain model itu dapat berupa cara mengoperasikan sesuatu, dan sebagainya. Dengan begitu, guru memberi model tentang bagaimana cara belajar.

Nuryatin (2010:34) menyatakan bahwa pemodelan dapat diartikan sebagai upaya pemberian model (contoh) yang berhubungan dengan materi dan aktivitas pembelajaran yang dilakukan siswa. Pemodelan harus dilakukan secara terencana agar memberikan sumbangan pada pemahaman dan keterlibatan siswa dalam proses pembelajaran, sehingga hasil belajar mengalami peningkatan. Pemodelan dikatakan efektif apabila siswa menjadi lebih paham terhadap materi yang dipelajari, terlibat dengan lebih antusias, memberikan variasi situasi, biaya dan waktu lebih efisien.

Teknik pemodelan merupakan bagian dari pendekatan kontekstual. Teknik pemodelan merupakan sebuah pengetahuan atau keterampilan yang dapat didemonstrasikan atau 
ada model yang dapat ditiru. Model tidak hanya terpaku pada guru atau siswa, melainkan model dapat dilihat dan didengar oleh seseorang.

Menurut Sugiyanto (2008:22) pemodelan merupakan konsep belajar yang memberikan contoh kepada siswa dalam proses pembelajaran sehingga siswa dapat mempelajari pengetahuan dari model atau contoh yang dihadirkan guru. Dengan demikian, pemodelan merupakan asas yang penting dalam pembelajaran karena siswa dapat terhindar dari pengetahuan yang bersifat teoris dan abstrak.

Pemodelan di dalam pengajaran merupakan kegiatan pembelajaran yang dilakukan guru dengan memperagakan pelajaran kepada siswanya sehingga dapat menarik perhatian siswa terhadap pelajaran yang diajarkan. Dengan pemodelan siswa secara langsung dapat melihat, mengamati, mendengar, merasakan sendiri materi yang diajarkan oleh guru. Dengan demikian, guru berkewajiban mewujudkan bahan yang diajarkan sekonkret mungkin, baik benda aslinya ataupun berupa benda tiruannya dalam bentuk model-model.

Berdasarkan uraian di atas bisa dianalogikan dengan teknik pemodelan dalam mengajar, maka pengertian teknik pemodelan adalah pemberian contoh mengajar kepada guru dengan tujuan memberikan gambaran yang jelas cara mengelola kelas yang baik.

Kondisi yang terjadi saat ini pembelajaran hanya memusatkan pada metode pembelajaran ceramah, siswa diharuskan untuk menghafal materi yang diberikan oleh guru dan tidak untuk menghubungkan materi tersebut dengan keadaan sekarang (kontekstual). Aktivitas guru mendominasi kelas dengan metode ekspositori, dan siswa hanya menerima apa yang disampaikan oleh guru, begitupun aktivitas siswa untuk menyampaikan pendapat sangat kurang, sehingga siswa menjadi pasif dalam belajar, dan belajar siswa kurang bermakna karena lebih banyak hapalan. Akhirnya menimbulkan kebosanan, sehingga siswa yang aktif akan melakukan aktifitas di luar kendali guru. Siswa tidak mengikuti kegiatan pembelajaran karena tidak ada ketertarikan.

Metode ekspositori adalah metode pembelajaran yang digunakan dengan memberikan keterangan terlebih dahulu definisi, prinsip dan konsep materi pelajaran serta memberikan contoh-contoh latihan pemecahan masalah dalam bentuk ceramah, demonstrasi, tanya jawab dan penugasan. Siswa mengikuti pola yang ditetapkan oleh guru secara cermat. Penggunaan metode ekspositori merupakan metode pembelajaran mengarah kepada tersampaikannya isi pelajaran kepada siswa secara langsung.

Penggunaan metode ini siswa tidak perlu mencari dan menemukan sendiri fakta-fakta, konsep dan prinsip karena telah disajikan secara jelas oleh guru. Kegiatan pembelajaran dengan menggunakan metode ekspositori cenderung berpusat kepada guru. Guru aktif memberikan penjelasan atau informasi pembelajaran secara terperinci tentang materi pembelajaran. Metode ekspositori sering dianalogikan dengan metode ceramah, karena sifatnya sama-sama memberikan informasi.

Pemodelan dalam penelitian ini merupakan demonstrasi atau pemberian contoh tentang cara mengelola kelas. Dengan begitu, kepala sekolah memberi model tentang bagaimana mengelola kelas. Pemodelan pada dasarnya membahasakan gagasan yang dipikirkan, mendemonstrasikan bagaimana kepala sekolah menginginkan gurunya untuk belajar dan melakukan apa yang kepala sekolah inginkan.

Pemodelan dilakukan secara terencana agar memberikan sumbangan pada pemahaman dan keterlibatan guru dalam proses pembelajaran, sehingga kemampuan guru dalam mengelola kelas mengalami peningkatan. Pemodelan dikatakan efektif apabila guru menjadi lebih paham terhadap cara pengelolaan kelas, terlibat dengan lebih antusias, memberikan variasi situasi, dan waktu lebih efisien.

Pengelolaan kelas yang baik dapat mempengaruhi tingkat kualitas pembelajaran di kelas, kualitas belajar siswa mencapai hasil yang optimal dan kompetensi dasar yang diharapkan dapat tercapai dengan baik dan memuaskan, tingkat daya serap materi yang telah diajarkan guru akan lebih membekas dalam ingatan siswa karena adanya penguatan yang diberikan guru selama proses belajar mengajar berlangsung. Pengelolaan kelas yang baik juga akan menciptakan dan mempertahankan suasana kelas agar kegiatan mengajar dapat berlangsung secara efektif dan efisien. Energi yang dikeluarkan guru tidak terkuras oleh hal-hal yang mestinya bisa dihindari. Cukup dengan teknik yang tepat guru bisa mengendalikan siswa. 
Dengan penggunaan teknik pemodelan diharapkan guru mendapatkan inspirasi dan menambah referensi guru dalam mengelola kelas. Langkah-langkah pemodelan diawali dengan pemberian pembinaan bagaimana mengelola kelas yang baik, dilanjutkan dengan pemberian contoh mengajar. Setelah menyaksikan pemodelan guru diobservasi bagaiman mengelola kelas ketika mengajar. Pada akhir proses pemodelan guru memiliki kemampuan dalam mengelola kelas.

Mengacu pada latar belakang di atas, maka masalah yang akan dijelaskan dalam penelitian ini yaitu bagaimana mengimplementasikan teknik pemodelan dalam meningkatkan pengelolaan kelas dan bagaimanakah cara meningkatkan kemampuan guru dalam mengelola kelas melalui teknik pemodelan di SD Muhammadiyah wonokromo II.

\section{METODE PENELITIAN}

Tempat penelitian tindakan sekolah ini di SD Muhammadiyah Wonokromo II yang beralamatkan di Dusun Dahromo, Segoroyoso, Pleret, Bantul, Daerah Istimewa Yogyakarta. SD Muhammadiyah Wonokromo II memiliki jumlah peserta didik 141. Jumlah guru kelas 6, guru bidang studi 4, seorang kepala sekolah dan seorang operator. Secara geografis SD Muhammadiyah Wonokromo terletak di desa, jauh dari perkotaan. Sisi utara sekolah dekat dengan Sungai Opak, sedangkan sisi selatan sekolah merupakan perbukitan.

Penelitian dilaksanakan pada semester II tahun pelajaran 2017/2018 pada bulan Februari sampai dengan Mei 2018. Subjek penelitian adalah guru di SD Muhammadiyah Wonoromo II. Guru di SD Muhammadiyah Wonokromo II sejumlah 5 orang terdiri dari seorang guru bidang studi Pendidikan Agama Islam dan empat guru kelas digunakan sebagai subjek penelitian dengan pertimbangan: nilai mata pelajaran yang diampu guru tersebut dan pada kelas tersebut pada Ulangan Harian sebelumnya rendah yaitu 69 di bawah nilai KKM 75. Alasan yang kedua guru PAI dan guru kelas 1, 2, 3 dan 4 kemampuan pengelolaan kelasnya rendah. Berdasarkan nilai hasil supervise rata-rata mencapai 72 sedangkan target yang harus dicapai 85. Melihat keadaan seperti itu menunjukkan adanya kesenjangan antar harapan dan kondisi nyata di sekolah. Berdasarkan pertimbangan tersebut, maka guru mata pelajaran PAI dan guru kelas 1, 2, 3 dan 4 ditetapkan peneliti sebagai subjek penelitian.
Penelitian tindakan sekolah ini menggunakan model siklus dari Elliot, setiap siklus terdiri atas empat tahap kegiatan yaitu: the planning of the action (rencana tindakan), the implementation of the action (implementasi tindakan), classroom observation (observasi kelas), dan the reflection of the action (refleksi tindakan). Tindakan yang diterapkan pada subjek dalam penelitian ini adalah meningkatkan kemampuan mengelola kelas melalui teknik pemodelan.

Penelitian ini dilaksanakan dalam 2 siklus dimana setiap siklus terdiri dari 4 tahapan yaitu: (1) the planning of the action (perencanaan), (2) the implementation of the action (implementasi tindakan), (3) class observation or monitoring and evaluation (observasi kelas dan evaluasi), (4) data analysis and reflection of the action (analisis data dan refleksi tindakan).

Kegiatan yang dilakukan dalan planning adalah merencanakan pembinaan terhadap guru. Pembinaan dilakukan dengan diskusi, penjelasan tentang pengelolaan kelas dan merencanakan pemodelan. Peneliti membuat RPP pembinaan terhadap guru, RPP pemodelan, membuat instrumen observasi dan menyusun jadwal. Pada tahap perencanaan ini penulis melaksanakan persiapan sebagai berikut: merencanakan pembinaan terhadap guru; membuat Rencana Pelaksanaan Pembelajaran pemodelan; menyusun media pembelajaran; membuat intrumen penelitian; lembar observasi RPP pembimbingan; lembar observasi pembimbingan; lembar observasi RPP pemodelan; lembar observasi keterlibatan siswa dalam KBM Pemodelan; lembar observasi pengelolaan kelas pemodelan; lembar observasi RPP guru; lembar observasi keterlibatan siswa dalam $\mathrm{KBM}$; lembar observasi pengelolaan kelas / guru mengajar; membuat jadwal penelitian; melakukan validasi instrumen penelitian dengan melibatkan kolaborator.

Acting mencakup pelaksanaan bimbingan dan pemodelan. Melaksanakan bimbingan terhadap guru yang menjadi subjek penelitian. Tahap ini peneliti melakukan diskusi dengan guru tentang pengelolaan kelas yang baik. Beberapa hal yang disampaikan tentang pengertian pengelolaan kelas, prinsipprinsip pengelolaan kelas, tujuan pengelolaan kelas, keterampilan pengelolaan kelas, serta kendala-kendala yang dihadapi guru dalam 
pengelolaan kelas. Setelah diskusi selesai, dilanjutkan dengan pemodelan. Tindakan atau perlakuan yang diterapkan dalam penelitian ini adalah sobjek penelitian mengobservasi guru model dalam mengajar dengan membawa instrumen observasi pengelolaan kelas. Setelah selesai mengobservasi dilakukan diskusi antara guru model peneliti dengan subjek penelitian.

Observing berupa mengamati guru dalam menyusun perencanaan dan pelaksanaan proses belajar mengajar. Pada tahap observing, peneliti mengobservasi subjek penelitian dalam membuat RPP, mengobservasi kegiatan belajar mengajar dan mengobservasi keaktifan siswa dalam kegiatan belajar mengajar. Fokus observasi pada pengelolaan kelas dan respon siswa dalam mengikuti pembelajaran. Observasi pembuatan RPP dimaksudkan untuk mengamati media dan metode serta skenario pembelajaran yang digunakan guru. Observasi menggunakan lembar instrumen observasi. Observasi dilakukan oleh kepala sekolah dan kolabulator. Di akhir pembelajaran guru melakukan penilaian. Penilaian ini juga dicatat sebagai nilai hasil belajar siswa yang juga menjadi indikator kompetensi guru.

Reflecting berupa membandingkan kompetensi guru dengan indikator keberhasilan. Kompetensi guru dan indikator keberhasilan dibuat dalam data kuantitatif. Kompetensi guru berupa kemampuan mengelola kelas dilihat dari hasil observasi pembuatan RPP, pelaksanaan KBM, dan keterlibatan siswa dalam KBM. Sedangkan indikator keberhasilan sudah ditentukan $85 \%$. Lembar observasi RPP berisi beberapa hal yang harus ada dan yang harus dilakukan guru dalam membuat RPP.

Instrumen yang digunakan berbentuk ratingscale yaitu alat untuk memperoleh data yang berupa suatu daftar yang berisi tentang sifat/ciri-ciri tingkah laku subjek penelitian yang ingin diselidiki yang harus dicatat secara bertingkat. Jenis rating yang digunakan adalah skala numeris. Angka dalam kebanyakan skala rating digunakan sebagai anchor, dan penggunaan angka ini didefinisikan secara jelas. Di belakang setiap deskripsi disediakan ruang untuk membubuhkan tanda $\sqrt{ }$ yang menunjukkan kesesuaiannya dengan subjek yang diamati. Observer hanya menandai angka yang menjadi pilihannya yaitu angka $1-4$.
Masing-masing angka memiliki makna tersendiri. $1=$ kurang, $2=$ cukup, $3=$ baik, $4=$ sangat baik. Hasil dari rating seluruh item yang menjadi pilihan observer dijumlahkan kemudian dibandingkan dengan indikator keberhasilan. Misalnya seluruh rating dari semua item 4 sehingga jumlah rating 100 . Maka kompetensi guru tersebut $100 \%$. Nilai seratus dibandingkan dengan indikator keberhasilan yaitu $85 \%$. Perbandingan antara kompetensi guru dan indikator keberhasilan adalah 100\%: 85\%. Ini berarti Guru sudah memiliki kompetensi yang tinggi. Jika hasil rating $65 \%$ maka perbandingan antara kompetensi guru dan indikator keberhasilan adalah $65 \%$ : $85 \%$. Ini berarti Guru memiliki kompetensi yang rendah. Jika perbandingan antara kompetensi guru lebih rendah dibanding dengan indikator keberhasilan maka dilanjutkan ke siklus kedua.

Penelitian ini menggunakan dua macam data yaitu primary data (data utama) dan supporting data (data pendukung). Data utama berupa hasil observasi pembuatan RPP, hasil observasi pengelolaan kelas saat subjek penelitian mengajar, dan hasil observasi keterlibatan siswa dalam KBM. Data pendukung berupa hasil penilaian akhir pelajaran. Instrumen yang digunakan berbentuk ratingscale yaitu alat untuk memperoleh data yang berupa suatu daftar yang berisi tentang sifat/ciri-ciri tingkah laku subjek penelitian yang ingin diselidiki yang harus dicatat secara bertingkat. Jenis rating yang digunakan adalah skala numeris. Observer atau rater hanya menandai angka yang menjadi pilihannya yaitu angka 1 - 4. Masing-masing angka memiliki makna tersendiri. $1=$ kurang, $2=$ cukup, $3=$ baik, 4 = amat baik. Hasil dari rating seluruh item yang menjadi pilihan observer dijumlahkan kemudian dibandingkan dengan indikator keberhasilan.

Teknik analisis data dalam penelitian ini melalui beberapa tahap. Data yang diperoleh berupa lembar observasi dalam proses pembelajaran, yaitu lembar observasi pengelolaan kelas dan lembar observasi keaktifan siswa, serta tes hasil belajar siswa pada akhir siklus (atau setiap pertemuan). Data yang dianalis adalah: Analisis data obsrvasi pengelolaan kelas dan observasi keaktifan siswa, serta tes hasil belajar siswa pada akhir siklus. Analisis menggunakan rerata hasil observasi dan tes, selanjutnya hasil rerata 
dideskripsikan untuk masing masing instrumen. Analisis deskriptif ini digunakan untuk mendeskripsikan karakteristik data hasil penelitian dan menjawab permasalahan yang tercantum dalam rumusan masalah. Analisis deskriptif yang digunakan dalam penelitian ini untuk data prestasi siswa adalah skor minimum, skor maksimum, rerata, dan presentase. Berdasarkan kriteria ketuntasan belajar apabila mencapai nilai minimal 75 untuk skala 100. Sedangkan untuk observasi RPP, pengelolaan kelas, dan keterlibatan siswa nilai pencapaiannya dikatakan berhasil jika rata-rata persentase siswa mencapai nilai lebih dari atau sama dengan 85 .

\section{HASIL PENELITIAN \\ Pra Siklus}

Kondisi pembelajaran di kelas pada pra siklus masih konvensional. Kemampuan guru dalam mengelola kelas masih rendah, hal ini dapat dilihat dari suasana kelas yang kurang kondosif, aktifitas siswa yang kurang terkontrol, minat siswa dalam belajar kurang, siswa tidak semangat dalam melaksanakan kegiatan pembelajaran, kurang motivasi, sehingga berdampak pada rendahnya nilai belajar siswa. Data hasil supervisi akademik pada prasiklus terangkum pada tabel di bawah ini.

Tabel 1. Rangkuman hasil supervisi akademik Pra Siklus

\begin{tabular}{lcc}
\hline \multicolumn{1}{c}{ Item } & Nilai Rata-rata supervisi & Indikator keberhasilan \\
\hline RPP & $72 \%$ & $85 \%$ \\
Pengelolaan Kelas & $72 \%$ & $85 \%$ \\
Keaktifan Siswa & $69 \%$ & $85 \%$ \\
Nilai Siswa & $69 \%$ & $75 \%$ \\
\hline
\end{tabular}

Tabel 1 memberikan gambaran bahwa kompetensi guru dalam membuat RPP, pengelolaan kelas, keatifan siswa masih jauh di bawah indikator keberhasilan. Kenyataan tersebut terjadi karena kompetensi guru di bidang pengelolaan kelas masih rendah. Proses pembelajaran cenderung menyampaikan materi kepada siswa. Pengelolaan kelas tidak optimal, perhatian terhadap siswa kurang menyeluruh.

\section{Siklus I}

Penelitian Tindakan Sekolah pada siklus I dilaksanakan pada tanggal 3 maret sampai dengan 20 Maret 2018. Kegiatan Siklus I meliputi perencanaan, implementasi, observasi, dan analisis data serta refleksi tindakan. Kegiatan yang dilakukan dalam perencanaan adalah merencanakan pembinaan terhadap guru. Pembinaan dilakukan dengan diskusi, penjelasan tentang pengelolaan kelas dan merencanakan pemodelan. Peneliti membuat RPP pembinaan terhadap guru, RPP pemodelan, membuat instrumen observasi dan menyusun jadwal. Acting mencakup pelaksanaan bimbingan dan pemodelan. Observing berupa mengamati guru dalam menyusun perencanaan dan pelaksanaan proses belajar mengajar. Sedangkan reflecting berupa membandingkan kompetensi guru dengan indikator.
Tahap perencanaan dilaksanakan hari Jumat, 2 Maret sampai dengan hari Rabu, 7 Maret 2018 Pada tahap ini yang dilakukan oleh peneliti adalah: a) menyusun perencanaan pembinaan terhadap guru, b) menyusun RPP pembimbingan, c) menyusun materi pembimbingan, d) menyusun RPP pemodelan, e) menyusun instrumen untuk observasi aktivitas siswa, f) menyusun instrumen untuk observasi pengelolaan kelas oleh guru dan g) menyusun instrumen untuk observasi RPP guru, h) menyusun instrumen untuk observasi keterlibatan siswa dalam KBM.

Pada tahap pelaksanaan kegiatan ini peneliti melakukan pembinaan tentang pengelolaan kelas dengan sistem diskusi, penyampaian materi, dan pemberian contoh pengelolaan kelas. Setelah pembinaan selesai dilakukan, langkah selanjutnya adalah observasi. Observasi kelas dilakukan dengan tujuan untuk mengetahui tingkat partisipasi atau keaktifan siswa dalam proses pembelajaran. Hal ini juga sebagai bentuk evaluasi terhadap proses pembelajaran. Lembar observasi yang digunakan berupa lembar checklist. Indikator yang diamati adalah tingkat partisipasi siswa dalam proses $\mathrm{KBM}$ 
Tabel 2. Rangkuman Analisi Hasil Observasi Siklus I

\begin{tabular}{|c|c|c|c|c|c|c|c|c|}
\hline \multirow{2}{*}{ Item } & \multicolumn{5}{|c|}{ Nilai Observasi Guru } & \multirow{2}{*}{ Rerata } & \multirow{2}{*}{$\begin{array}{c}\text { Indikator } \\
\text { keberhasilan }\end{array}$} & \multirow{2}{*}{ Kesenjangan } \\
\hline & I & II & III & IV & $\mathrm{V}$ & & & \\
\hline RPP & $65 \%$ & $72 \%$ & $65 \%$ & $72 \%$ & $63 \%$ & $68 \%$ & $85 \%$ & $17 \%$ \\
\hline $\begin{array}{l}\text { Pengelolaan } \\
\text { Kelas/KBM }\end{array}$ & $77 \%$ & $77 \%$ & $74 \%$ & $80 \%$ & $72 \%$ & $76 \%$ & $85 \%$ & $9 \%$ \\
\hline Keaktifan Siswa & $75 \%$ & $72 \%$ & $72 \%$ & $75 \%$ & $65 \%$ & $72 \%$ & $85 \%$ & $13 \%$ \\
\hline Nilai Siswa & $71 \%$ & $71 \%$ & $70 \%$ & $72 \%$ & $68 \%$ & $70,4 \%$ & $75 \%$ & $4,6 \%$ \\
\hline
\end{tabular}

Tabel 2 dapat dibaca bahwa hasil observasi RPP terhadap guru kelas 1, guru kelas 2, guru kelas 3, guru kelas 4, dan guru Pendidikan agama Islam rata-rata dari kelima guru yang menjadi subjek penelitian mendapat skor $68 \%$. Hasil observasi terhadap pengelolaan kelas mendapat skor $76 \%$. Hasil observasi terhadap keaktifan siswa mendapat skor $72 \%$. Hasil observasi terhadap nilai yang diperoleh siswa mendapat skor $70,4 \%$. Dari kelima item yang diobservasi skor terendah pada kemampuan membuat RPP. Sedangkan perolehan skor tertinggi pada kompetensi pengelolaan kelas yaitu mendapat skor $76 \%$.

Berdasarkan skor capaian kompetensi guru masih lebih rendah dibandingkan dengan indikator keberhasilan. Kompetensi pembuatan RPP mendapatkan skor 68\%, sementara indikator keberhasilan $85 \%$. Ini berarti masih ada kesenjangan $7 \%$. Hasil observasi terhadap pengelolaan kelas mendapat skor $76 \%$ dan hasil observasi terhadap keaktifan siswa mendapat skor $72 \%$ sedangkan indikator keberhasilan $85 \%$. Ini berarti masih ada kesenjangan $13 \%$. Hasil observasi terhadap nilai yang diperoleh siswa mendapat skor $70,4 \%$, sementara indikator keberhasilan $75 \%$. Ini berarti masih ada kesenjangan 4,6\%. Oleh karena itu untuk mencapai ketuntasan dilanjutkan dengan siklus II.

\section{Siklus II}

Siklus II dilaksanakan pada tanggal 23 Maret sampai dengan 11 April 2018. Pada tahap perencanaan peneliti melaksanakan kegiatan: a) menyusun perencanaan pembinaan terhadap guru, b) menyusun RPP pemodelan, c) menyusun instrumen untuk observasi aktivitas siswa, d) menyusun instrumen untuk observasi pengelolaan kelas oleh guru, dan e) menyusun instrumen untuk observasi RPP guru.

Pelaksanaan Tindakan Siklus II peneliti melaksanakan pembinaan terhadap guru. Guru dikumpulkan secara berkelompok diberi pembinaan. Isi pembinaan berupa bagaimanakah membuat RPP yang lengkap, bagaimana mengelola kelas yang baik, menarik, dan dapat mencapai tujuan, serta bagaimana dapat memusatkan perhatian siswa agar antusias dalam mengikuti pelajaran.

Observasi kelas dilakukan oleh peneliti dan dibantu oleh kolaborator. Kolabulator mengobservasi peneliti dalam membuat RPP pembimbingan, saat peneliti melakukan pembimbingan, RPP KBM model, pengelolaan kelas saat model mengajar, dan keterlibatan siswa dalam mengikuti KBM guru model. Peneliti melakukan observasi RPP guru, pengelolaan kelas saat guru mengajar, dan keterlibatan siswa dalam mengikuti pembelajaran guru. Observasi dilakukan dengan tujuan untuk mengetahui tingkat partisipasi atau keaktifan siswa dalam proses pembelajaran. Hal ini juga sebagai bentuk evaluasi terhadap proses pembelajaran. Lembar observasi yang digunakan berupa lembar checklist. Indikator yang diamati adalah tingkat partisipasi siswa dalam proses KBM.

Tabel 3. Rangkuman Analisi Hasil Observasi Siklus II

\begin{tabular}{|c|c|c|c|c|c|c|c|c|}
\hline \multirow{2}{*}{ Item } & \multicolumn{5}{|c|}{ Nilai Observasi } & \multirow{2}{*}{ Rerata } & \multirow{2}{*}{$\begin{array}{c}\text { Indikator } \\
\text { keberhasilan }\end{array}$} & \multirow{2}{*}{ Keterangan } \\
\hline & Guru I & Guru II & Guru III & Guru IV & Guru V & & & \\
\hline Rpp & $89 \%$ & $86 \%$ & $86 \%$ & $89 \%$ & $86 \%$ & $87 \%$ & $85 \%$ & Tuntas \\
\hline $\begin{array}{l}\text { Pengelolaan } \\
\text { Kelas/Kbm }\end{array}$ & $90 \%$ & $87 \%$ & $90 \%$ & $87 \%$ & $85 \%$ & $88 \%$ & $85 \%$ & Tuntas \\
\hline $\begin{array}{l}\text { Keaktifan Siswa } \\
\text { Nilai Siswa }\end{array}$ & $\begin{array}{l}90 \% \\
82 \%\end{array}$ & $\begin{array}{l}90 \% \\
81 \%\end{array}$ & $\begin{array}{l}87 \% \\
78 \%\end{array}$ & $\begin{array}{l}87 \% \\
80 \%\end{array}$ & $\begin{array}{l}85 \% \\
79 \%\end{array}$ & $\begin{array}{l}88 \% \\
80 \%\end{array}$ & $\begin{array}{l}85 \% \\
75 \%\end{array}$ & $\begin{array}{l}\text { Tuntas } \\
\text { Tuntas }\end{array}$ \\
\hline
\end{tabular}

Hasil observasi RPP terhadap guru kelas 1 , guru kelas 2, guru kelas 3, guru kelas 4, dan guru Pendidikan agama Islam mendapat skor yaitu $87 \%$. Hasil observasi terhadap 
pengelolaan kelas mendapat skor $88 \%$. Hasil observasi terhadap keaktifan siswa mendapat skor $88 \%$. Hasil observasi terhadap nilai yang diperoleh siswa mendapat skor $80 \%$. Indikator keberhasilan membuat RPP, Pengelolaan kelas, keterlibatan siswa ditetapkan $85 \%$, sedangan hasil belajar siswa ditetapkan $75 \%$.
Perbandingan antara skor capaian dengan indikator keberhasilan menunjukkan adanya peningkatan antara siklus satu dan siklus dua. Bila dibandingkan dengan indikator keberhasilan sudah melampaui indikator keberhasilan atau tuntas.

Tabel 4. Progres Capaian Kompetensi Guru dari Suklus I ke Siklus II

\begin{tabular}{lcccc}
\hline \multicolumn{1}{c}{ Kompetensi } & Siklus I & Siklus II & $\begin{array}{c}\text { Indikator } \\
\text { Keberhasilan }\end{array}$ & Keterangan \\
\hline Penyusunan RPP & $68 \%$ & $87 \%$ & $85 \%$ & Mengalami kenaikan 19\% \\
Kemampuan pengelolaan kelas & $76 \%$ & $88 \%$ & $85 \%$ & Mengalami kenaikan 12\% \\
Keterlibatan siswa & $72 \%$ & $88 \%$ & $85 \%$ & Mengalami kenaikan 16\% \\
Hasil penilaian siswa & $70,4 \%$ & $80 \%$ & $75 \%$ & Mengalami kenaikan 9,6\% \\
\hline
\end{tabular}

\section{SIMPULAN}

Berdasarkan uraian hasil penelitian yang dilakukan terhadap guru kelas 1, kelas 2, kelas 3, kelas 4 dan guru PAI di SD Muhammadiyah Wonokromo II pada bulan Februari sampai dengan Mei 2018, maka dapat ditarik kesimpulan bahwa teknik pemodelan dapat diimplementasikan dalam meningkatkan kompetensi guru bidang pengelolaan kelas. Kompetensi guru dalam pengelolaan kelas di SD Muhammadiyah Wonokromo II dapat ditingkatan dengan teknik pemodelan.

Saran yang perlu disampaikan adalah: 1) Salah satu kesuksesan dalam teknik pemodelan adalah peneliti mengenal dengan siswa di kelas yang akan menjadi objek pemodelan. Sementara peneliti belum tentu mengenal nama-nama siswa karena tidak berinteraksi langsung secara mendetail sehingga ketika mengajar ada kendala untuk memanggil nama siswa. Untuk itu peneliti menyarankan kepada peneliti berikutnya agar sebelum melakukan pemodelan melakukan pendekatan dulu terhadap siswa atau memberikan kartu nama di tempel di dada siswa untuk mempermudah menyebutkan namanya; 2) Penelitian ini menghasilkan temuan penting yaitu adanya peningkatan kompetensi guru dalam membuat RPP, mengelola kelas, dan peningkatan nilai siswa. Berdasarkan temuan tersebut dapat dijadikan bahan pertimbangan bagi kepala sekolah untuk menggunakan teknik pemodelan dalam proses pembinaan terhadap guru. Hasil penelitian ini juga dapat dijadikan sebagai bahan pertimbangan bagi kepala sekolah untuk menggunakan teknik pemodelan sehingga dapat meningkatkan prestasi belajar siswa.

\section{DAFTAR RUJUKAN}

Arikunto, S. dkk. 2009. Penelitian Tindakan Kelas. Jakarta: PT Bumi Aksara

Djamarah dan Zain. 2006. Strategi Belajar Mengajar. Jakarta: Rineka Cipta

Hadari Nawawi. 1989. Organisasi Sekolah dan Pengelolaan Kelas. Jakarta: Haji Masagung

Mulyasa, E. 2007. Standar Kompetensi dan Sertifikasi Guru. Bandung: Remaja Rosdakarya

Mulyasa, E. 2012. Penelitian Tindakan Sekolah. Bandung: Remaja Rosdakarya

Mulyasa, E. 2017. Menjadi Guru Profesional. Bandung: Remaja Rosdakarya

Nurhadi dan Senduk 2003. Pembelajaran Kontekstual (Contextual Teaching and Learning). Malang: Universitas Negri Malang

Nuryatin, Agus. 2010. Mengabadikan Pengalaman dalam Cerpen. Rembang:

Yayasan Adhigama

Rimy, Yoko. 2017. Implementasi Penelitian Tindakan Kelas. Yogyakarta: Sahara

Rusman. 2016. Model-model Pembelajaran. Jakarta: Raja Grafindo Persada

Sugiyanto. 2008. Model-model Pembelajaran Inovatif. Surakarta: Yuma Pustaka

Suharsimi Arikunto. 1988. Pengelolaan Kelas dan Siswa sebuah Pendekatan Evaluatif. Jakarta: Rajawali Pers 